\title{
Age dynamic of physical condition changes in pre-school age girls, schoolgirls and students, living in conditions of Eastern Siberia
}

\author{
Lebedinskiy V.Y. ${ }^{1}$, Koipysheva E.A. ${ }^{1}$, Rybina L.D. ${ }^{1}$, Kudryavtsev M.D. ${ }^{2,3,6,7}$, \\ Iermakov S.S. ${ }^{4}$, Osipov A.Yu. ${ }^{2,5}$, Sidorov L.K. ${ }^{6}$ \\ ${ }^{1}$ Irkutsk National Research Technical University, Russia \\ ${ }^{2}$ Siberian Federal University, Russia \\ ${ }^{3}$ Reshetnev Siberian State University of Science and Technology, Russia \\ ${ }^{4}$ Gdansk University of Physical Education and Sport, Poland \\ ${ }^{5}$ Professor V.F. Voino-Yasenetsky Krasnoyarsk State Medical University, Russia \\ ${ }^{6}$ Krasnoyarsk State Pedagogical University of V.P. Astafyev, Russia \\ ${ }^{7}$ The Siberian Law Institute of the Ministry of Internal Affair of Russia, Russia
}

\begin{abstract}
Purpose:

to analyze dynamic of physical condition, considering sex (females) and age of the tested, living in region with unfavorable ecology.

Material: $\quad$ we studied pre school age girls ( $n=1580$, age 4-7 years). In the research we did not include children with chronic diseases, who were under observation. We tested schoolgirls ( $n=3211$, age $7-17$ years) and girl students ( $n=5827$, age 17-21 years, 1-4 years of study. Girl students were divided into five age groups: from 17 to 21 years. All participants lived in conditions of Eastern Siberia (Irkutsk). This region is characterized by unfavorable ecology and climate geographic characteristics.

Results: $\quad$ in dynamic of physical condition of pre-school girls, schoolgirls and students we marked out three substantial periods of it characteristics' changes. Age 7-8 years is critical (transition from 1st to 2nd stage). The least values of these characteristics are found in older (after 17-18 years) ages. In students we observed relative stabilization of these indicators.

Conclusions: the received results shall be considered in building physical education training process in pre-school educational establishments, secondary comprehensive schools and higher educational establishments.

Keywords: pre school age girls, schoolgirls, girl students, physical condition.
\end{abstract}

\section{Introduction}

Physical education is one of leading criteria, improvement of whose indicators shall witness about health strengthening of rising generation. This criterion is external manifestation of adequacy of growth and development processes to living conditions and age [14]. Its assessment shall be built on comparison of testing results with test requirements and on dynamic of its results' increment. Such assessment shall be realized for every age group [12].

Single studies of morphological or functional indicators permit to assess only physical condition of the tested. These indicators cannot serve as the base for assessment of population physical state [6]. Dynamic observations shall include complex analysis of indicators. It will permit to predict reliably child's development and his/her functional potentials [13]. With it, it is necessary to consider homogeneity of group results, to admit tolerance for age and processes of natural growth and development of children, adolescents and youth [3].

The basis for monitoring of population's physical state (of all age groups) is: unfavorable medical-demographic situation; insufficiently effective system of first medical aid organization; growth of somatic morbidity; harmful habits and negative social phenomena [8].

System of monitoring permits to actually assess harmony of children's adolescents and youth's development [11]. It is the base for working out of correction programs, directed at health strengthening

(c) Lebedinskiy V.Y., Koipysheva E.A., Rybina L.D., Kudryavtsev M.D., lermakov S.S., Osipov A.Yu., Sidorov L.K., 2017 doi:10.15561/20755279.2017.0604 and physical fitness improvement. The main sphere of practical application of monitoring is information servicing of its management [12].

In other studies authors note demand in the following: consideration of youth's individual features in physical culture $[21,27]$ and sport practicing $[24,26]$; choice of optimal loads [30] and adequate motor tests [22, 25] as well as health level $[32,33]$.

Unfavorable ecological and climate geographic characteristics of Irkuts region influence negatively on the following: rising generation's physical development and physical fitness [4]; main medical demographic indicators (birth rate, mortality and morbidity. With it, their values in population of Eastern Siberia are much lower than in population of European and central parts of Russia. For children's population of Siberian region's industrial cities some morphological functional peculiarities are characteristic. These peculiarities are connected with living conditions and specific of environmental pollution [7].

In other works it is noted that climatic conditions influence on pre school age children's perception of motor tasks [22]. These peculiarities shall be considered when preparing motor training programs [28]. Besides, it is recommended that members of family, peers and sportsmen were examples in programs of youth's physical activity's increasing (on example of Australia) [34]. Such approach facilitates formation of positive attitude to own health and involves youth in active sports' practicing [29, 31]. It is noted that physical culture teachers shall have certain competences. It was found that application of 
information-communication technologies is an important factor, which influences on teachers' competences in Turkey [20].

In Irkutsk region specialists in physical culture and medicine rarely analyzed dynamic of children's population's physical development. Only some weight height indicators of this age group were regarded and compared with average indicators in Russia. Besides, there are practically no scientifically substantiated regional standards of assessment of rising generation's physical health. Only in 2002-2014 the group of scientists, guided by Prof. V.Yu. Lebedinskiy fulfilled work on monitoring of pre schoolchildren's physical development [17], schoolchildren [18] and students [2] of Irkutsk. The authors considered age, gender and typological characteristics of children and youth.

Hypothesis: study of physical development peculiarities of pre school girls, schoolgirls and girl students will permit to raise effectiveness of physical education in municipal pre school educational (MPSEE) and comprehensive schools (MEE SCS) and in higher educational establishments.

The purpose of the research was to analyze dynamic of pre school girls, schoolgirls and girl students, living in region with unfavorable ecology, physical condition.

\section{Material and methods}

Participants: 1.pre school age girls. We tested girls ( $\mathrm{n}=1580$, age 4-7 years), who attended MPSEE № 75, 79, 148 in Irkutsk. In the research we did not include children with chronic diseases, who were under observation.

2. Schoolgirls: we tested girls $(n=3211$, age $7-17$ years), who learn in 22, 25, 44 of MEE SCS in Irkutsk.

3. Girl students: we tested girls $(n=5827$, age 17-21 years, 1-4 years of study), who study in Irkutsk national research technical university (IrSRTU). The girl students were divided into 5 age groups: from 17 to 21 years age.

All parents gave consent for their children's participation in the research. The protocol of the research was approved by ethic committee of Irkutsk national research technical university.

Organization of the research: the main complex of this research's methods was worked out as per special program [1]. We found main indicators of physical development and physical fitness and methods of their study [9].

The studies were conducted from September 2004 to May 2007 - twice a year: at the beginning (September) and at the end (May) of academic year. We used: anthropometric measurements (height, weight, chest circumference -CC) and physiometric examinations (dynamometry) of physical development.

Statistical analysis: the received data were processed with Microsoft Excel 7.1., «Statistica 6.1» programs. Confidence of average values' differences in independent samples was assessed by Student's t-test.

\section{Results}

In our work we used only those data, which (according to monitoring) can be observed in age from 4 to 21 years age (see table 1).

Research of height parameters' changes in the tested pre school age girls, schoolgirls and girl students can be conventionally divide into four periods (see fig. 1).

1. Body length of girls from 4 to six years age increases

Table 1. Physical development of pre school age girls, schoolgirls and girl students

\begin{tabular}{llllll}
\hline Age & Height $(\mathbf{c m})$ & Weight $\mathbf{( k g )}$ & $\begin{array}{l}\text { Chest } \\
\text { circumference } \\
(\mathbf{c m})\end{array}$ & $\begin{array}{l}\text { Right hand } \\
\text { dynamometry } \mathbf{( k g )}\end{array}$ & $\begin{array}{l}\text { Left hand } \\
\text { dynamometry }(\mathbf{k g})\end{array}$ \\
\hline $\mathbf{4}$ years & $102,5 \pm 0,3$ & $16,3 \pm 0,1$ & $51,1 \pm 0,1$ & $1,3 \pm 0,1$ & $1,0 \pm 0,1$ \\
$\mathbf{5}$ years & $108,0 \pm 0,3^{*}$ & $18,0 \pm 0,1^{*}$ & $52,7 \pm 0,1^{*}$ & $2,2 \pm 0,1^{*}$ & $1,7 \pm 0,1^{*}$ \\
$\mathbf{6}$ years & $114,6 \pm 0,2^{*}$ & $19,9 \pm 0,1^{*}$ & $54,3 \pm 0,1^{*}$ & $3,2 \pm 0,1^{*}$ & $2,5 \pm 0,1^{*}$ \\
$\mathbf{7}$ years & $123,8 \pm 0,5^{*}$ & $23,4 \pm 0,4^{*}$ & $57,3 \pm 0,4^{*}$ & $11,1 \pm 0,2^{*}$ & $9,3 \pm 0,3^{*}$ \\
$\mathbf{8}$ years & $127,0 \pm 0,3^{*}$ & $25,1 \pm 0,3^{*}$ & $58,7 \pm 0,3^{* *}$ & $12,0 \pm 0,2^{* *}$ & $10,1 \pm 0,2^{* *}$ \\
$\mathbf{9}$ years & $131,2 \pm 0,4^{*}$ & $27,7 \pm 0,3^{*}$ & $60,8 \pm 0,3^{*}$ & $13,1 \pm 0,2^{*}$ & $11,1 \pm 0,2^{*}$ \\
$\mathbf{1 0}$ years & $137,9 \pm 0,4^{*}$ & $31,2 \pm 0,3^{*}$ & $62,2 \pm 0,3^{* *}$ & $13,9 \pm 0,2^{*}$ & $11,8 \pm 0,2^{* *}$ \\
$\mathbf{1 1}$ years & $144,9 \pm 0,4^{*}$ & $35,2 \pm 0,3^{*}$ & $64,2 \pm 0,2^{*}$ & $15,4 \pm 0,1^{*}$ & $12,9 \pm 0,1^{*}$ \\
$\mathbf{1 2}$ years & $150,6 \pm 0,3^{*}$ & $39,2 \pm 0,3^{*}$ & $66,4 \pm 0,2^{*}$ & $17,0 \pm 0,1^{*}$ & $14,6 \pm 0,1^{*}$ \\
$\mathbf{1 3}$ years & $156,7 \pm 0,3^{*}$ & $44,7 \pm 0,4^{*}$ & $68,4 \pm 0,2^{*}$ & $18,9 \pm 0,2^{*}$ & $16,4 \pm 0,2^{*}$ \\
$\mathbf{1 4}$ years & $160,5 \pm 0,3^{*}$ & $48,6 \pm 0,4^{*}$ & $69,8 \pm 0,2^{*}$ & $20,9 \pm 0,2^{*}$ & $17,9 \pm 0,4^{*}$ \\
$\mathbf{1 5}$ years & $163,0 \pm 0,3^{*}$ & $51,7 \pm 0,4^{*}$ & $70,7 \pm 0,3^{* *}$ & $22,9 \pm 0,2^{*}$ & $19,9 \pm 0,2^{*}$ \\
$\mathbf{1 6}$ years & $164,2 \pm 0,4^{*}$ & $53,9 \pm 0,6^{* *}$ & $72,1 \pm 0,4^{* *}$ & $24,2 \pm 0,3^{*}$ & $21,2 \pm 0,3^{*}$ \\
$\mathbf{1 7}$ years & $164,9 \pm 0,2$ & $55,2 \pm 0,7$ & $74,2 \pm 0,5^{* *}$ & $25,8 \pm 0,4^{* *}$ & $22,5 \pm 0,4^{* *}$ \\
$\mathbf{1 8}$ years & $165,0 \pm 0,5$ & $55,3 \pm 0,2$ & $83,9 \pm 0,4^{*}$ & $26,6 \pm 0,3^{*}$ & $24,6 \pm 0,2$ \\
$\mathbf{1 9}$ years & $165,0 \pm 0,2$ & $55,8 \pm 0,2$ & $86,3 \pm 0,3^{*}$ & $26,7 \pm 0,2$ & $24,8 \pm 0,2$ \\
$\mathbf{2 0}$ years & $165,1 \pm 0,1$ & $56,1 \pm 0,2$ & $86,6 \pm 0,4$ & $27,1 \pm 0,1$ & $25,0 \pm 0,3$ \\
$\mathbf{2 1}$ years & $165,5 \pm 0,3$ & $56,1 \pm 0,3^{* *}$ & $88,1 \pm 0,2^{*}$ & $27,7 \pm 0,2$ & $25,3 \pm 0,1^{* *}$ \\
\hline
\end{tabular}

$\mathrm{P} * * *<0,05, \mathrm{P} * *<0,01, \mathrm{P} *<0,001$ in respect to previous age 
by $6 \mathrm{~cm}(\mathrm{P}<0,001)$ a year. The highest value $(\mathrm{P}<0,001)$ of yearly increment (by $9.2 \mathrm{~cm}$ ) was registered in 7 years age children.

2. $\mathrm{Y}$ In 8 and 9 years age girls increment $(\mathrm{P}<0,05)$ of this indicator reduces to $4 \mathrm{~cm}$ a year.

3. From 10 to 13 year age change of height again becomes noticeable $(\mathrm{P}<0,001)$ increases to $6-7 \mathrm{~cm}$ a year. By 14 years $(\mathrm{P}<0,05)$ these indicators are $4 \mathrm{~cm}$ a year.

4. From 15 to 21 years age increment of this indicator significantly reduces $(\mathrm{P}<0,05)$. From 17 years to 21 years age this indicator practically does not change $(\mathrm{P}>0,05$.

Increase of body mass of the tested (see fig. 2) is conventionally divided into 3 stages.
1. From 4 to 9 years it increases by $2-3 \mathrm{~kg}$ a year $(\mathrm{P}<0,05)$.

2. From 10 to 15 years age in schoolgirls significant weight increase is observed $(\mathrm{P}<0,001)$ by $3-5 \mathrm{~kg}$.

3. From sixteen years the girls weight increment $(\mathrm{P}>0,05)$ is insignificant - less than $1 \mathrm{~kg}$ a year.

In changes of chest circumference (see fig. 3) we can also conventionally mark out three stages:

1. From 4 to 6 years age we observe significant increase $(\mathrm{P}<0,001)$ of indicator is by $1.6 \mathrm{~cm}$ a year.

2. In seven years girls it is higher $-3 \mathrm{~cm}(\mathrm{P}<0,001)$, and in next ages up to 17 years age inclusively it changes $(\mathrm{P}<0,05)$ from 1 to $2,2 \mathrm{~cm}$ a year.

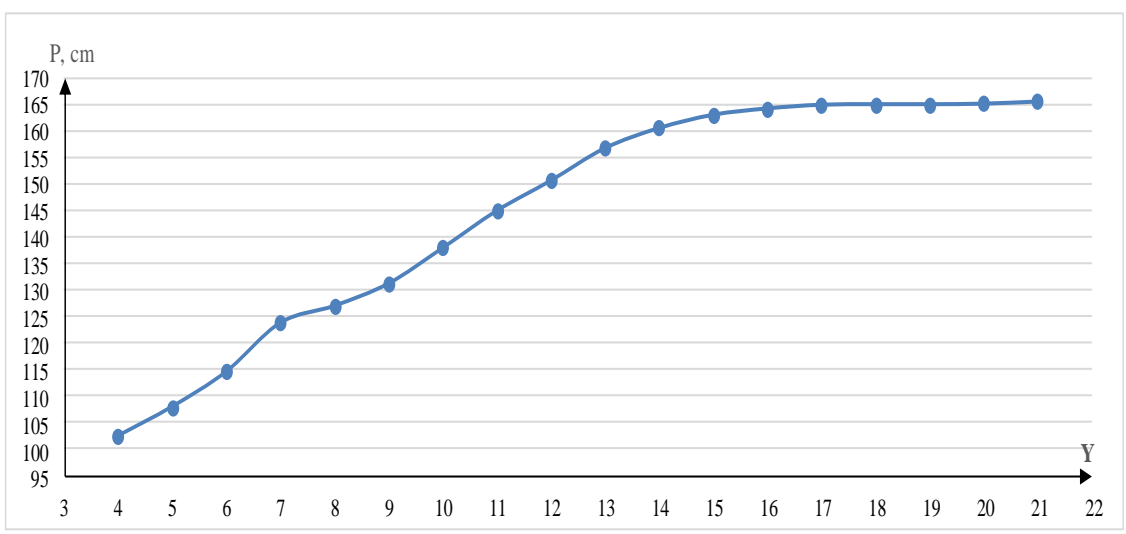

Fig. 1. Dynamic of $P$ (height, $\mathrm{cm}$ ) indicators' changes from $Y$ (age, years)

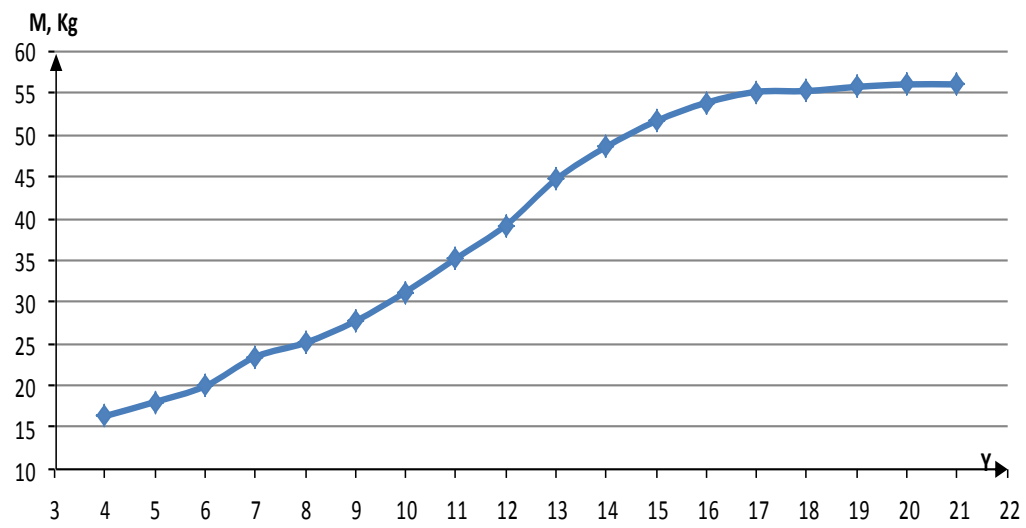

Fig. 2. . Dynamic of $M, k g$ (weight) indicators' changes from $Y$ (age, years)

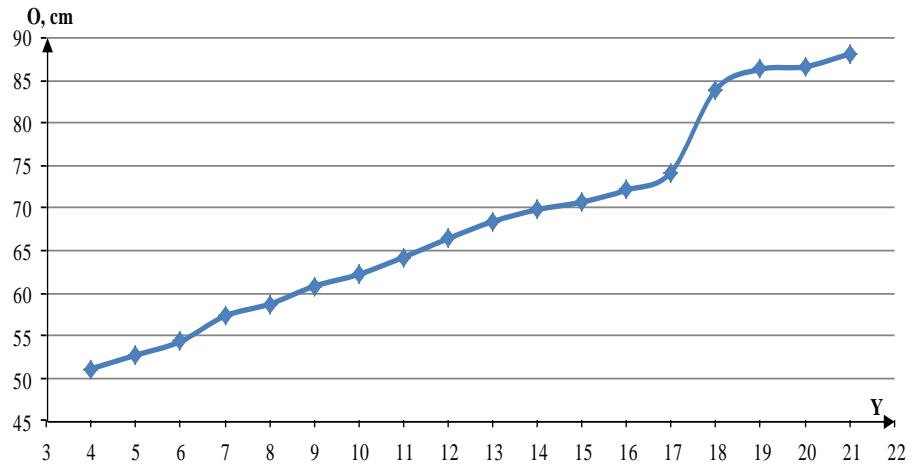

Fig. 3. Dynamic of CC (chest circumference, $\mathrm{cm}$ ) indicators' changes from $Y$ (age, years) 
3. In 18 years age the stage starts from the most significant $C C$ increment $(P<0,001)(9.7 \mathrm{~cm})$. Nest years (up to 21 year) its changes are less expressed $(\mathrm{P}>0,05)$ (to $2,4 \mathrm{~cm}$ a year).

Dynamic of left and right hand strength changes (fig. 4, 5 ) has the same character and can also be conventionally divided into 3 stages:

1. From 4 to 6 years it is characterized by little $(\mathrm{P}<0,05)$ change of muscles' strength - up to $1 \mathrm{~kg}$ a year.

2. In seven years girls we observed the highest increment $(\mathrm{P}<0,001)$ of right and left hands' strength: 7-9 and $6-8 \mathrm{~kg}$ accordingly. In next ages up to 17 year age (right hand) and 18 -left hand these indicatorsincrease relatively uniformly by $0,7-2,1 \mathrm{~kg}$ a year. It should be noted that age 11-13 years (right hand) and 12-15 years (left hand) is characterized by more expressed $(\mathrm{P}<0,001)$ increments of indicator.

3. In 18 years age and older right and left hands strength increases insignificantly $(\mathrm{P}>0,05)$ to $0,8 \mathrm{~kg}$ a year.

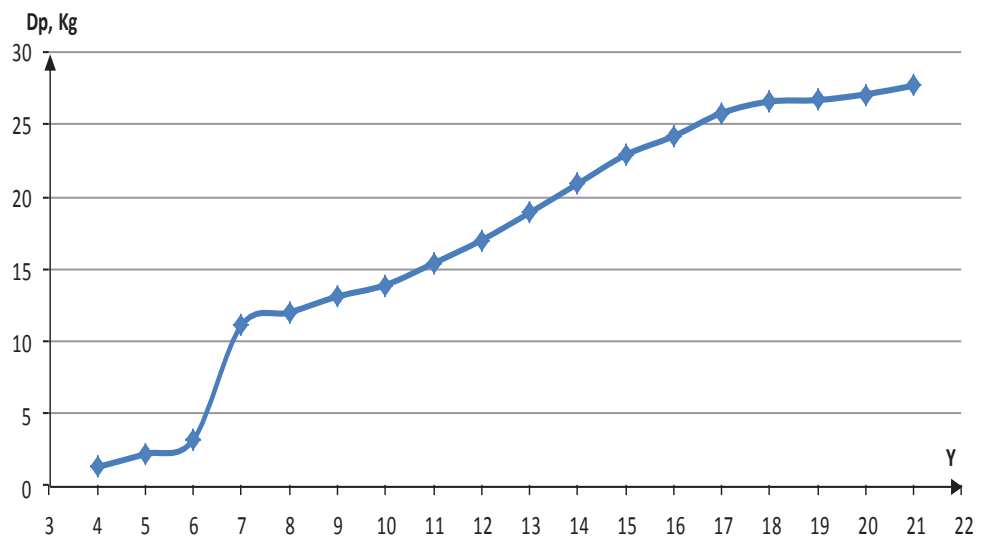

Fig. 4. Dynamic of right hand dynamometry indicators' change (Dp, $K g$ ) from $Y(Y$, years)

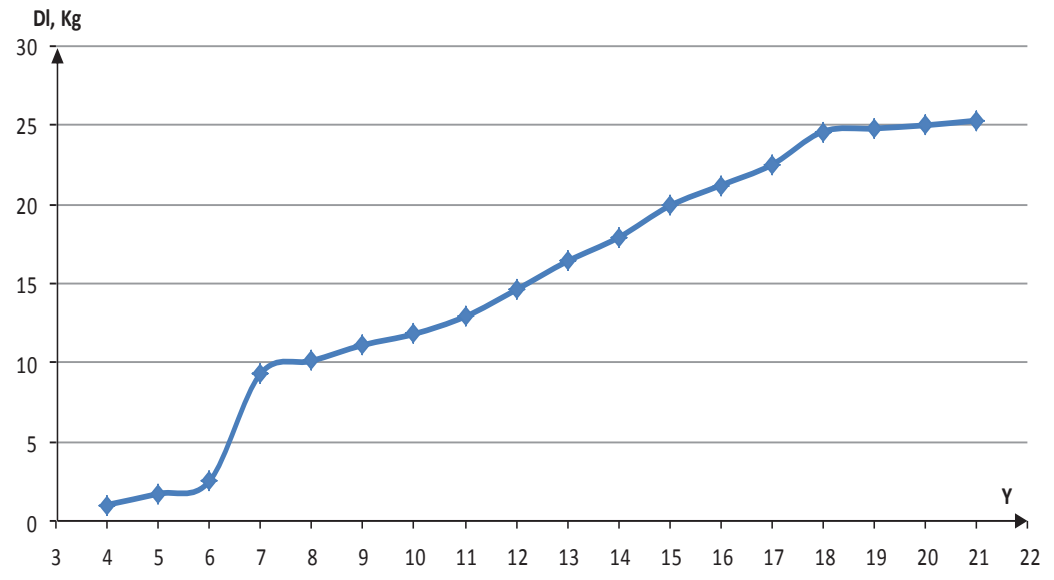

Fig. 5. Dynamic of left hand dynamometry indicators' change (Dp, $\mathrm{Kg})$ from $Y(Y$, years)

$\mathrm{P}$

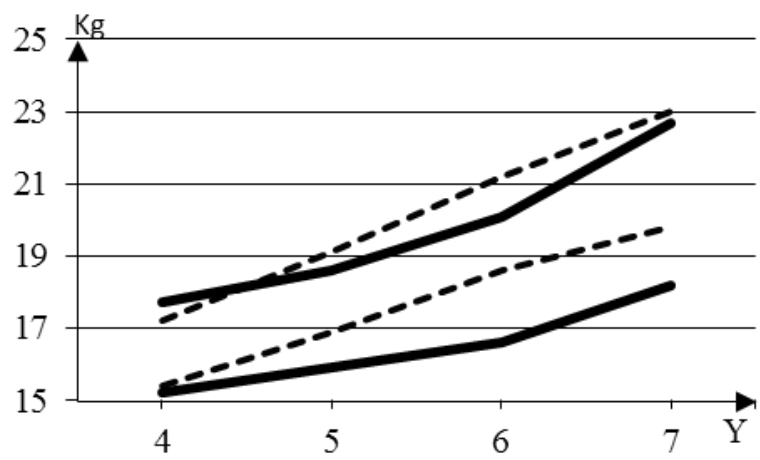

Fig. 6. Comparative characteristics of weight $(P, \mathrm{Kg})$ from age $(Y$, years)
$\mathrm{P}$

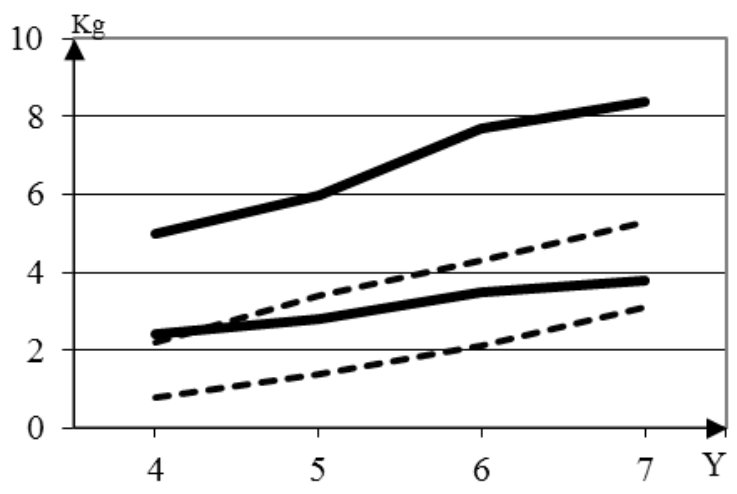

Fig. 7. Right hand dynamometry $(\mathrm{P}, \mathrm{Kg})$ from $\mathrm{Y}(\mathrm{Y}$, years) 


\section{Discussion}

By results of physical condition comparison in children from MPSEE (Irkutsk) with children from other regions of Russian Federation we found the following: in 4 years pre school age girls height parameters do not differ significantly from general Russian standards [17]; in 5 and 6 years age their height parameters improve and go ahead of their peers; in 7 yrs age - they coincide.

In the plots below the borders of regional standards of pre school age girls physical condition (Irkutsk) are depicted by dotted line; continuous line - general Russian standards.

Weight parameters of 4 years Irkutsk pre school age girls (see fig. 6) also do not noticeably differ from average values in Russia.

By 5 and 6 years their parameters improve and go ahead their peers; in seven years they again practically coincide with general Russian standards.

By CC dimensions Irkutsk pre school age girls yield their peers of 4 and 5 years age. Then, in 6 and 7 years age theses dimensions increase and reach general Russian standards, though remaining a little less than general Russian standards. Analysis of vital capacity of lungs' indicators (VCL) of 4-5 Irkutsk girls show the following: $\mathrm{CC}$ was a little less that in their peers from other regions. Since 6 years this indicator improves and by 7 years age coincides with general Russian standards.

When analyzing right hand dynamometry indicators we found that in 4 years age Irkutsk girls show absolute low results, comparing with peers from other Russian regions. Then they start to reach the peers from other Russian regions, though this indicator of them is still lower (see fig. 7).

The same picture is noticed in left hand dynamometry. In 4 years age Irkutsk girls demonstrate very low results. But, by 7 yrs age results increase. They have lower indicators even better than in other Russian regions.

Comparing of Irkutsk girls regional standards with general Russian indicators permits to make conclusion that by height and body weight 5-6 yrs age Irkutsk girls are before their peers. However, by CC, VCL and left and right dynamometry indicators are less in all ages. Especially these distinctions are expressed in 4-5 yrs age. From 6 to 7 years the borders of regional standards

$\mathrm{O}$

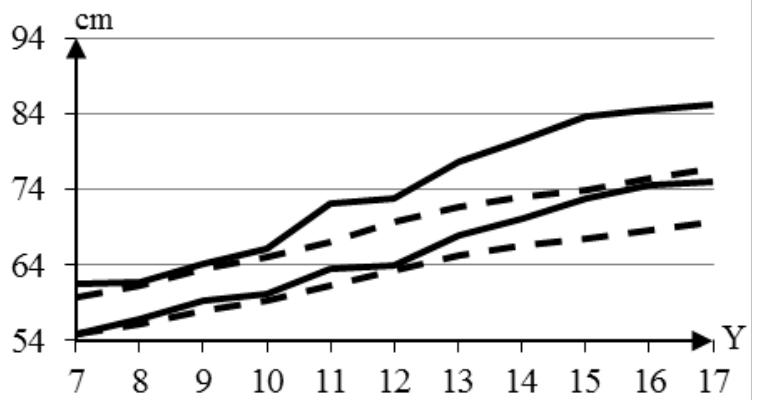

Fig. 8 .Comparative CC characteristics: $\mathrm{O}-\mathrm{cm}$; $\mathrm{Y}-$ age, years expand and approach to general Russian to some extent.

When comparing age dynamic of some indicators of schoolgirls' physical condition (Irkutsk, 7-17 yrs age) with general Russian standards we found some differences [18]. It is determined by living conditions in Eastern Siberia.

It was found that their height parameters do not differ from average characteristics in Russia. But, form 11 to 14 years age their height parameters improve and become a little better than their peers' in other regions. By 15 yrs age height parameters again practically coincide with general Russian data Changes of weight indicators also practically coincide with general Russian standards. Especially it is noticeable in 16-17 yrs age.

When analyzing CC characteristics we noted that from 10 yrs age Irkutsk schoolgirls lag behind for their peers in other regions. It is the most expressed since 13 yrs age (see fig. 8). Analysis of VCL changes of Irkutsk schoolgirls shows that its indicators also were lower that in their peers from other regions.. They practically correspond each other only in 7 yrs age. Then, in Irkutsk schoolgirls they become a little higher (in 8 yrs age) and we observed the tendency to their increase up to 17 yrs age.

Changes of right hand dynamometry indicators show that in Irkutsk schoolgirls from 7 to 13 yrs age they are higher than in their peers from other regions. These indicators are compared in 14 and 15 yrs. By 16-17 yrs age they do not practically differ (see fig. 9). In age 7-10 yrs age they are much higher.

The same picture can be seen by left hand dynamometry: Irkutsk schoolgirls (especially in 7-10 years) have advantage over their peers. These indicators are less expressed in 11-15 yrs age. In 16-17 yrs age these indicators do not differ.

When comparing physical condition standards with their peers from other regions it was found that they are practically equal by height and weight. In a number of indicators advantage of general Russian standards is registered only in senior school age. In junior age differences smooth. Especially it is expressed from 12 years age. From 7 to 12 yrs age Irkutsk schoolgirls have better results in left and right hands dynamometry.

Analyzing students' physical development [2] we

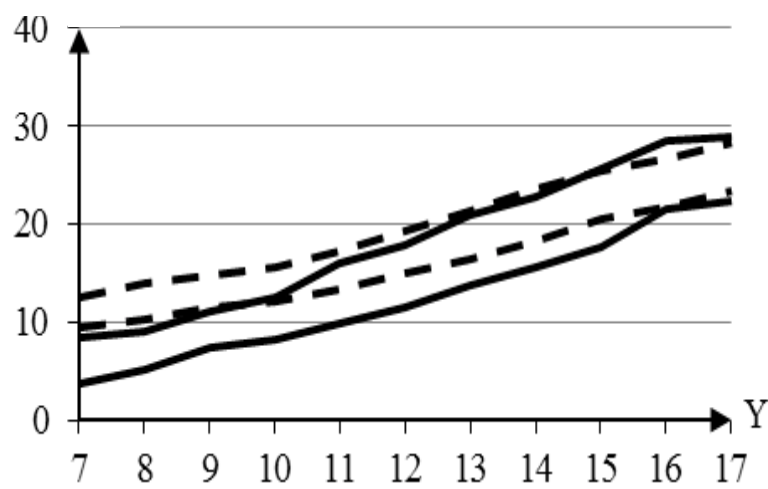

Fig. 9. Right hand dynamometry $(\mathrm{P}, \mathrm{Kg})$ from $\mathrm{Y}(\mathrm{Y}$, years) 
found that their anthropometric indicators practically do not change. Physio-metric indicators, which differ more intensively and confidently during first two years of study at university demonstrate deeper changes. At senior years of study their stabilization happens.

Comparing physical condition of different age girl students we found:

- We did not observe significant differences in physical condition indicators (weight, height). But from 17 to 21 yrs age they insignificantly change.

- In CC characteristics we registered significant в ( $\mathrm{P}<0,001)$ differences 18, 19 and 21years;

- We found noticeable changes in dynamometry of left and right hands in 18 and 20 yrs age $(\mathrm{P}<0,01)$.

\section{Conclusions:}

1. Physical condition's indicators of Irkustk schoolgirls can be divided into three main periods. The most expressed their increment was registered in pre school age.

$7-8$ yrs age is the most critical (transition from $1^{\text {st }}$ to $2^{\text {nd }}$ stage) After 18 yrs age we registered relative stabilization of indicators. It shall be considered in building educational process in schools and HEEs.

2 . The created bank of testing results and worked out standards of Irkutsk girls' physical condition (4-21 yrs age) can serve as the base for further scientific researches of physical condition of different population strata.

3. Application of monitoring [14] over physical condition of pre school age girls, schoolgirls and girl students in MPSEE, MEE and HEE permits:

- Assess initial level of physical and motor conditions;

- Correct educational and educational-training processes;

- Assess successfulness of their mastering of motor skills;

- Fulfill comparative characteristics of different population strata physical health (age, class, group and so on);

- To assess effectiveness of physical culture a instructors' and teachers' work.

The received results can be used in educational and training work in MPSEE, MEE and physical culture departments of other HEEs of region. The results are innovative technology of physical education with application of individual differentiated training at physical culture lessons and in sports practicing.

\section{Conflict of interests}

The authors state that there is no conflict of interest.

\section{References}

1. Vinogradov PA. Functioning of Goskomsport of Russia on population, children's, adolescents' and youth's physical health monitoring. Moscow; 2002. (in Russian)

2. Epifanova MG. Monitoring of girl students' physical condition and physical fitness. Irkutsk: IrSTU Publ.; 2014. (in Russian)

3. Zav'ialov AI. Perfection of schoolchildren's physical education. Irkutsk; 2007. (in Russian)

4. Ignat'eva EP. Physical condition and physical fitness of third functional health group's students. Irkutsk: IrSTU Publ.; 2014. (in Russian)

5. Izaak SI. Monitoring of physical condition and physical fitness. Moscow: Soviet sport; 2005. (in Russian)

6. Izaak SI, Lebedinskiy VY. Organization of rising generation's mass health examinations in Irkutsk region. International scientific methodic conference "Physical culture and sports in development of health formation and health protection technologies, "East-Russia-West", Irkutsk; 2005. P. 198201. (in Russian)

7. Koipysheva EA. Dynamic of technical HEE girl students' physical development (second functional health group). Vestnik IrGTU, 2013;4(75):254-261. (in Russian)

8. Koipysheva EA, Rybina LD, Lebedinskiy VY. Physical condition and physical fitness of pre school age girls, schoolgirls and girl students of Irkutsk. Teoriia i praktika fizicheskoj kul'tury. 2016;4:41-43. (in Russian)

9. Komkov AG. Social-pedagogic monitoring of physical activity, health and cultural development indicators. Teoriia $i$ praktika fizicheskoj kul 'tury, 1998;6:2-7. (in Russian)

10.Kuchma VR. Health indicators of children and adolescents in modern system of social hygienic monitoring Gigiena $i$ sanitariia. 2004;6:14-16. (in Russian)

11.Landa BKh. Methodic of physical condition and physical fitness complex assessment. Kazan; 2000. (in Russian)
12.Lebedinskiy VY. Monitoring of HEE educational processes' subjects health "Health Passport". Irkutsk: IrSTU Publ.; 2008. (in Russian)

13.Lebedinskiy VY. Monitoring of physical health as factor of physical education's pedagogic orientation strengthening in non profile HEEs. Teoriia i praktika fizicheskoj kul'tury, 2014;10:98-101. (in Russian)

14.Lebedinskiy VY. Physical development of pre school age girls, school girls and girl students. Irkutsk: IRNITU Publ.; 2016. (in Russian)

15.Lubysheva LI, Malinin AV. Study of Russian schoolchildren's health and behavior. Fizicheskaia kul'tura: vospitanie, obrazovanie, trenirovka. 2004;6:16-22. (in Russian)

16. Rybina LD. Analysis of technical HEE girl students' physical condition during academic year (first functional health group). Vestnik Irkutskogo gosudarstvennogo tekhnicheskogo universiteta, 2014;2(85):312-316. (in Russian)

17.Tiapin AN. Physical culture passport: methodic recommendations on test program. Moscow: VNIIFK; 1998. (in Russian)

18.Gerasimova IN, Larina MV, Lebedinskiy VY, Sidorova IIu. Physical condition and physical fitness of Itkutsk children population: pre school age children. Irkutsk: ISTU; 2012. (in Russian)

19.Sidorova IIu, Gerasimova IN, Larina MV, Lebedinskiy VY. Physical condition and physical fitness of Itkutsk children population: school children. Irkutsk: ISTU; 2012. (in Russian)

20.Arslan Y. Determination of Technopedagogical Content Knowledge Competencies of Preservice Physical Education Teachers: A Turkish Sample. Journal of Teaching in Physical Education. 2015;34(2):225-41.

21.Druz VA, Iermakov SS, Nosko MO, Shesterova LYe, Novitskaya NA. The problems of students' physical training individualization. Pedagogics, psychology, medical- 
biological problems of physical training and sports, 2017; 21(2): 4-12. doi:10.15561/18189172.2017.0201

22.Hastie PA, Rudisill ME, Boyd K. An ecological analysis of a preschool mastery climate physical education programme. Physical Education and Sport Pedagogy. 2016;21(2):217-32.

23.Hastie PA, Wellhead T. Models-Based Practice in Physical Education: The Case for Sport Education. Journal of Teaching in Physical Education. 2016;35(4):390-9.

24.Jagiello W. Differentiation of the body composition in taekwondo-ITF competitors of the men's Polish national team and direct based athletes. Archives of Budo. 2015;11:329-38.

25.Khudolii OM, Ivashchenko OV, Iermakov SS, Rumba OG. Computer simulation of Junior gymnasts' training process. Science of Gymnastics Journal, 2016;8(3):215-228.

26.Kolling S, Wiewelhove T, Raeder C, Endler S, Ferrauti A, Meyer T, et al. Sleep monitoring of a six-day microcycle in strength and high-intensity training. European Journal of Sport Science. 2016;16(5):507-15.

27.Kozina ZL, Iermakov SS, Kadutskaya LA, Sobyanin FI, Krzeminski M, Sobko IN, Ryepko OA. Comparative characteristic of correlation between pulse subjective indicators of girl students' and school girls' reaction to physical load. Physical Education of Students. 2016;20(4):2434. doi:10.15561/20755279.2016.0403

28.MacLean J, Mulholland R, Gray S, Horrell A. Enabling curriculum change in physical education: the interplay between policy constructors and practitioners. Physical
Education and Sport Pedagogy. 2015;20(1):79-96.

29. Osipov AY, Kudryavtsev MD, Iermakov SS, Jagiello W. Topics of doctoral and postdoctoral dissertations devoted to judo in period 2000-2016 - the overall analysis of works of Russian experts. Arch Budo, 2017; 13: 1-10.

30.Podrigalo LV, Iermakov SS, Alekseev AF, Rovnaya OA. Studying of interconnections of morphological functional indicators of students, who practice martial arts. Physical Education of Students. 2016;20(1):64-70. doi:10.15561/20755279.2016.0109

31.Podrigalo LV, Iermakov SS, Jagiełł W. Special indices of body composition as a criterion of somatic development of martial arts practitioners. Arch Budo Sci Martial Art Extreme Sport 2017; 13: 5-12.

32.Radziminska A, Weber-Rajek M, Lulinska-Kuklik E, Kazmierczak U, Moska W. Academic youth's health behavior. Physical education of students, 2016; 20(6): 55-62. doi:10.15561/20755279.2016.0607

33.Radzimińska A, Weber-Rajek M, Lulińska-Kuklik E, Piecka P, Moska W. The impact of classical massage on spine mobility. Pedagogics, psychology, medical-biological problems of physical training and sports, 2017; 21(2): 82-86. doi:10.15561/18189172.2017.0206

34. Young JA, Symons CM, Pain MD, Harvey JT, Eime RM, Craike MJ, et al. Role models of Australian female adolescents: A longitudinal study to inform programmes designed to increase physical activity and sport participation. European Physical Education Review. 2015;21(4):451-66.

\section{Information about the authors:}

Lebedinskiy V. Y.; http://orcid.org/0000-0002-5291-8775; lebedinskiy@istu.ru; Irkutsk National Research Technical University; 83 Lermontov St., 664074, Irkutsk, Russia.

Koipysheva E. A.; http://orcid.org/0000-0003-4058-5085; koip00@mail.ru; Irkutsk National Research Technical University; 83 Lermontov St., 664074, Irkutsk, Russia.

Rybina L. D.; http://orcid.org/0000-0003-3666-1946; rybina.liuda2016@yandex.ru; Irkutsk National Research Technical University; 83 Lermontov St., 664074, Irkutsk, Russia.

Kudryavtsev M. D.; http://orcid.org/0000-0002-2432-1699; kumid@yandex.ru; Siberian Federal University; 79 Svobodny pr., Krasnoyarsk, 660041, Russia.; Reshetnev Siberian State University of Science and Technology; Office A-406, 31, Krasnoyarsky Rabochy Av., 660014, Krasnoyarsk, Russia.; Krasnoyarsk State Pedagogical University of V.P. Astafyev; Ada Lebedeva Street, 89, Krasnoyarsk, 660049, Russia.; The Siberian Law Institute of the Ministry of Internal Affair of Russia; Rokossovskia str., 20 , Krasnoyarsk, 660131, Russia.

lermakov S.S.; http://orcid.org/0000-0002-5039-4517; sportart@gmail.com; Gdansk University of Physical Education and Sport; Kazimierza Gorskiego 1, 80-336 Gdansk, Poland.

Osipov A.Yu.; http://orcid.org/0000-0002-2277-4467; Ale44132272@ya.ru; Siberian Federal University; 79 Svobodny pr., Krasnoyarsk, 660041, Russia.; Professor V.F. Voino-Yasenetsky Krasnoyarsk State Medical University; P. Zeleznyak, 1, Krasnoyarsk, 660022, Russia.

Sidorov L.K.; http://orcid. org/0000-0002-4337-8201; sidorovk@kspu.ru; Krasnoyarsk State Pedagogical University of V.P. Astafyev; Ada Lebedeva Street, 89, Krasnoyarsk, 660049, Russia.

Cite this article as: Lebedinskiy VY, Koipysheva EA, Rybina LD, Kudryavtsev MD, Iermakov SS, Osipov AYu, Sidorov LK. Age dynamic of physical condition changes in pre-school age girls, schoolgirls and students, living in conditions of Eastern Siberia. Physical education of students, 2017;21(6):280-286. doi:10.15561/20755279.2017.0604

The electronic version of this article is the complete one and can be found online at: http://www.sportedu.org.ua/index.php/PES/issue/archive

This is an Open Access article distributed under the terms of the Creative Commons Attribution License, which permits unrestricted use, distribution, and reproduction in any medium, provided the original work is properly cited (http://creativecommons.org/licenses/by/4.0/deed.en).

Received: 20.06.2017

Accepted: 15.07.2017; Published: 08.12.2017 